\title{
Organisational Variables \& Effective Performance of Employees in Oil \& Gas Section: An Empirical Investigation
}

\author{
Ajibola O. Ogunyemi ${ }^{1}$, Simeon. O. Akinlaja ${ }^{1}$, Emmanuel Adesoye ${ }^{1}$, Abayomi Akindele-Oscar ${ }^{1}$, Rasaq \\ Olugbenga Azeez ${ }^{1} \&$ Mark A. Omolade ${ }^{2}$ \\ ${ }^{1}$ Olabisi Onabanjo University, Ago-Iwoye, Nigeria \\ ${ }^{2}$ National Institute for Educational Planning and Administration (NIEPA) Nigeria \\ Correspondence: Ajibola O. Ogunyemi, Olabisi Onabanjo University, Ago-Iwoye, Nigeria. Tel: \\ 234-805-530-1472. E-mail: bolaogunyemi@ymail.com
}

Received: August 4, 2014

Accepted: November 7, $2014 \quad$ Online Published: February 17, 2015

doi:10.5539/ijps.v7n1p23

URL: http://dx.doi.org/10.5539/ijps.v7n1p23

\begin{abstract}
Formal work organizations are created to produce goods and services and to pursue dominant goals that individuals acting alone cannot achieve. However, the importance of some factors in the achievement of this objective cannot be overemphasized. This study examines the contribution of work environment, organisational culture, to employees' job performance. Ex-post facto research design was adopted. Proportional stratified and simple random sampling techniques were utilized to select 500 participants from three oil companies in River State, Nigeria $($ Agip $=150$, Schlumberger $=185$, Nigerian Agip exploration $=165)$. Two standardized self-report questionnaires were used for data generation. Two hypotheses were raised and tested using multiple regression and t-test statistics. Findings revealed among others that the two predictor variables (work environment and organisational culture) combined and individually, predicted the criterion variable (job performance). Based on the findings of this study, a number of recommendations were made among which are: employers of labour should provide suitable work environment for increased job performance of employees; and make the organizational culture favourable so as to enhance productivity of the work force.
\end{abstract}

Keywords: work environment, organisational culture, job performance, oil industry

\section{Introduction}

The importance of petroleum resource to the development of Nigeria as a nation is clearly reflected in the fact that it remains the goose that lay the golden egg for the Nation's economy as well as the supreme foreign exchange earner; contributing over $80 \%$ of government revenues and helps in the development of Nigeria's infrastructure and other industries (Anya, 2002; Chukwu, 2002; Garry \& Karl, 2003); thus, it is not an overstatement to say that petroleum production is as important to Nigerian economy as oxygen is to human life. Presently, Nigeria is the leading oil and gas producer in Africa (NNPC, 2004). The country is ranked $13^{\text {th }}$ largest oil producer in the world; and $6^{\text {th }}$ largest oil producer among the organization of petroleum exporting countries (OPEC). It ranks $5^{\text {th }}$ in gas reserves which make the country more of a gas rather than an oil country (CBN, 2002). Indeed, Nigeria is often described as a gas zone with some oil in it (Assael, 2000; Ekpu, 2004). Currently, Nigeria's crude oil production is about 2.3 million barrels per day; and it is expected to be 2.5 million (NNPC, 2004). The oil and gas industry has been described as the nation's life wire (Adidu \& Ogbene, 2005; Adegbulugbe, 2002).

However, due largely to the technical nature of exploration and production, the sector depends substantially on imported technology, equipment and manpower for its operations. As estimated, $\$ 8$ billion is spent annually on servicing the industry operation such as: fabrication, engineering procurement construction (EPC), front end engineering design (FEED), conceptual design and seismic studies. This figure is projected to hit $\$ 15$ billion within the next few years (Agbebaku \& Edeko, 2005). Regrettably, despite this huge sum of money spent in servicing the industry, only a very little proportion of the accruable profit is spent in Nigeria. Majority of the amounts are repatriated abroad, where most of the equipments are manufactured; and providing employment opportunities for citizens of other countries. The major reason for this situation has been attributed to low local content (LC), a situation where most of the service contracts are awarded to foreign firms because local indigenous firms lack the requisite skills, technical expertise, manpower and production capacity and capability 
to compete favourably (Ekpu, 2004). Adidu et al. (2005) and Agbebaku et al. (2005) expanded the above reasons for low local content in Nigeria to include: low technological capacity, lack of funding from financial institutions, inadequate and incoherent polices/legislations; inadequate infrastructures, unfavourable business climate etc. Adidu et al. (2005) and Ajakaiye (2001) in similar studies also expanded the problem to include inability of commercial banks to provide tenured loans to indigenous firms to execute project, among others.

It is so bad that upon the huge amount of money spent annually in servicing the operations of this sector, the oil and gas sector is still far from attaining its full production capacity (NNPC, 2004). Performance is results measurement. Therefore, any measure of an organisation's effectiveness must attempt to relate its actual performance to the standard or objective set. The only true measure of an employee's effectiveness is job performance; and it can be measured by comparing actual production with target production (Guion, 1997). Thus, in order to attain the target job performance level, performance standard must be established and it must be communicated to employee; actual performance must be measured; and comparison between the actual and standard performance must be analysed. If the sector depends largely on imported technology (both material and human) and such a huge amount of money ( $\$ 8$ billion) is expended annually on servicing the sector to ensure ultimate performance and this objective is still not being achieved, there may be more to it. This study is motivated by this realization.

Chandrasekar (2011) established that there is relationship between work place environmental factors such as job aid, supervisor support, opportunity to get promotion, performance feedback, goal setting, coaching, physical work environment and job performance of workers. Boles (2004) also affirm that employee-friendly work environment helps in reducing the number of absenteeism and thus can increase employees' performance. Shikdar and Swaqed (2013) established that workplace environmental factors have a very strong relationship with job performance. Improper workplace environment might result in physiological and psychological reactions that might affect job performance at a long term (Clement-Croome, 2006). The aforementioned research findings imply that for any business to thrive in a highly competitive business environment like oil and gas sector, labour employers must be aware of the potentials of workplace environmental factors that could have a great impact on performance level of workers.

Although, part of what determines high performance of workers may be sophisticated technology or state of the art equipment and high level manpower expertise. But the importance of other environmental factors such as organisational culture and work environment cannot be over-emphasized. Every work organization is concerned with being effective. Upon the attainment of its aims and objectives rests the success and ultimate survival of the organization. The quality of work environment and organisational culture are central to organisational development and employee improved performance.

Previous studies on organisational behaviour and job performance pay little attention to features of the physical environment in which work is performed. Yet, evidence is accumulating that the physical environment of work affects job performance (Vischer, 2007). Contemporary research on work environment typically focuses on psychosocial factors such as job attitude (e.g. Yusuf \& Metibola, 2012), socioeconomic status (e.g. Burnastein \& Fisk, 2003) that affect job performance and does not address the growing body of work on the environmental psychology of workplace. However, evidence is accumulating that the physical environment in which people work affects both job performance and job satisfaction (Clements-Croome, 2000; Newsham et al., 2004). This study aims at determining the contribution of work environment on job performance of employees in oil and gas sector, among others

Work environment has been described to reflect every situation and event that influence the way in which people live or work. Workplace environment consists of the relationship between work, tools of work and workplace (Chandrasekar, 2011). In other words, work environment is the totality of forces, actions and other influential factors that are currently and or potentially contending with the employee's activities and performance (Kohun, 1992; Chandrasekar, 2011). It is the sum of the interrelationship that exists within the employees and between the employees and the environment in which the employees work. The extent to which employees will benefit from collective knowledge within the organization is dependent on how the work environment is designed to suit employee's satisfaction. However, free flow of exchange of ideas is a better medium of motivating employees towards higher productivity. Work environment, when appropriately designed, motivates employees towards productivity (Viasher, 2007). This study thus seeks to empirically determine the contribution of work environment on job performance of employees.

Another variable of high importance in this study is organisational culture. In the midst of growing success among organisations, the role of organisational culture is becoming increasingly important. Large bodies of 
research (Argyle, 1989; Burnstein \& Fisk, 2003; Dasanayake \& Mahakalanda, 2008) and articles (Varelas, 2009; Cecunc, 2004) on the significance of cultural fit have all helped propel organisational culture into the spotlight. Moreover, the performance and success of organisations with well-defined workplace culture has spurred many scholars to be interested in investigating into the influence of organisational culture on employees' behaviour. As organisations constantly struggle to increase productivity, especially in this constantly changing and very volatile business world, one way to achieve competitive advantage is to begin with an organisation's internal culture. As the unknown, unspoken rule book of employee's behaviour, words and productivity. The ability of organisational culture to drive successes and actively support business outcomes is unmatched (Stewart, 2010; Varelas, 2009). Moreover, multiple office locations and globalization which are features of today's business are factors that further established the relevance of organisational culture in the work place. Organization culture has been shown to have an impact on important organisational outcomes such as performance, employee satisfaction and well-being among others (Burmer \& Evans, 2008). The operation of any organisation is very much influenced by their culture.

Schein (1992) and Shani and Lau (2005) affirm that organisational culture is more important than it was in the past. Increased competition, globalization, mergers, acquisitions, alliances and various workplace developments which are features of today's work organisation have created a greater need for coordination and integration of organisational units in order to improve efficiency, quality, and speed of designing, manufacturing, and delivering products and services. To such organisation like Nigerian oil and gas industries that rely heavily on imported technology, equipment and manpower (Ojo, 2010), effective management of dispersed work units and workforce diversity become a serious issue.

Cross-cultural management or multi-national partnerships is also a pointer to the relevance of organisational culture in industries like Nigerian oil and gas companies. A better understanding of organisational culture would allow employee to solve problems and improve organisational performance. While corroborating this view, Brooks (2006) suggests that an intimate knowledge and awareness of culture should improve ability to analyse organisational behaviour and consequently lead to effective management.

The implication of the above statement is that such understanding will translate into superior corporate performance. According to Mashane and Glinow (2005), culture assists the sense-making process. That is, it helps employees understand organisational events and consequently, employees can communicate more efficiently and effectively therefore, having mutual relationship with each other because they share common mental models of realities and this will lead to improved performance. The pervasive role culture plays in organisational life lends credence to the assumption that cultural factors may be linked with organizational performance. But as important as this construct seems to be, there is no agreement among scholars on the precise nature of the relationship between organisational culture and job performance. In other words, there is no widely accepted causal relationship between organisational culture and employees' job performance. The empirical evidences emerging from various studies on the effect of organizational culture on job performance have so far yielded mixed results that are inconclusive and sometimes contradictory (Dasanayake \& Mahakalanda, 2008; Ojo, 2010).

Furthermore, a review of academic literature on the subject of organisational culture and employees' job performance indicated that there is dearth of research work on the construct in developing countries, including Nigeria. In view of this contradictory research outcomes and the existing gap in the literature on the subject of organisational culture, especially in the less developed countries in general and Nigeria in particular, the question of whether organisational culture improves or worsens employees' job performance is worthy of further research.

Organisational culture is defined as a set of norms, beliefs, principles and ways of behaving that give each organisation a distinctive character (Brown, 1995). Wiegmann, Zhang, von Thaden, Sharma and Gibbons (2004) provide a summary of various definitions of safety culture and conclude that all the definitions have a number of common features, regardless of the industry being considered. Wiegmann et al. (2004) state that there are at least five organisational indicators of a safety organisational culture. These include organisational commitment, management involvement, employee empowerment, reward or accountability system and reporting system. Burman and Evans (2008) further explain that it is a set of assumptions shared by the individuals in an organisation that directs interpretation and action by defining appropriate behaviour for various situations; and this have great implication on employees' job performance. The present study therefore attempts to determine the contribution of organisational culture in specific statistical term to employee's job performance. To achieve this objective, two hypotheses tested at 0.05 significant levels were raised: 
Hypotheses

i. There is significant contribution of work environment and organisational culture in the prediction of job performance of employees in selected oil and gas industries in River state, Nigeria.

ii. There is significant relative contribution of work environment and organisational culture in the prediction of job performance of employees in selected oil and gas industries in River state, Nigeria.

\section{Method}

\subsection{Design and Participants}

This study employs the use of expost-facto research design. This is because the variables being investigated have already occurred and attempt is only being made to determine the influence of the predictor variables on the criterion measure.

Participants of this study were five hundred respondents selected through the use of proportional stratified and simple random sampling techniques from three oil companies (Agip=150, Schlumberger $=185$, Nigerian Agip exploration=165) in River state, Nigeria. The first stage of stratification was represented by the three oil and gas companies (i.e. Agip, Schlumberger and Agip exploration) and this was followed by the different departments in the selected oil and gas companies. The selection was based on the percentage of the population in each of the oil and gas company selected with no special reference to gender. The mean age of the participants was 33.2 years with a standard deviation of 3.1. Their ages ranged between 23 and 56 years.

\subsection{Instruments}

Three instruments and employees' appraisal forms were used for data collection. The instruments are described below:

\subsubsection{Demographic Data Form}

A form that contains demographic information of the participants was designed by the researchers. The form was used to collect the appraisal form of the selected participants from the human resources department of the three selected oil and gas companies. The form contains information such as: name of organisation, name of participant, gender, work experience staff cadre/position (i.e. junior/senior staff) etc.

\subsubsection{Work Environment Questionnaire (WEQ)}

A 29-item scale developed by Stringer (1998) who pioneered the study of climate in corporate environments was used to elicit response from the respondents. The questionnaire was designed in Likert format of strongly agree to strongly disagree; strongly agree was scored 5 , while strongly disagreed was scored 1 . Sample items in the scale include: "am encouraged to solve as many of my own work-related problems", "I believe in and take pride in my work and my workplace", "I feel accepted and valued by my colleagues.

The scale reported a reliability level of 0.80 and a validity level of 0.62 . The cronbach alpha of the scale in the present sample is 0.79 .

\subsubsection{Organisational Culture}

Organisational culture survey developed by Wiegmann et al. (2003) was adopted for this study. The scale evaluates safety culture with consideration on the following components: Organisational commitment, management involvement, employee empowerment, reward or accountability system and reporting system. Sample items in the scale include; "in my organisation, change is viewed as a challenge and an opportunity", "our strategic plan is evaluated once a year and revised as needed; "our products and services reflect the awareness of a diverse consumer base" The scale has a scoring format of almost always (4 point), often ( 3 point), sometime ( 2 point); and almost never ( 1 point). The reliability coefficient of the scale is 0.87 and its Cronbach alpha in the present study is 0.75 .

\subsubsection{Employee Appraisal Form}

Employee appraisal form: The human resources department of the 3 oil companies used in this study have a unified standardized employee appraisal forms and these appraisal forms of each sample used in this study as scored by their various heads of unit were collected for analysis to evaluate the job performance of the selected employees. 
Table 1. Demographic characteristic

\begin{tabular}{|c|c|c|c|}
\hline & CATEGORIES & FREQUENCY & PERCENTAGE \% \\
\hline \multirow[t]{3}{*}{ Gender } & Male & 371 & $75.3 \%$ \\
\hline & Female & 122 & $24.7 \%$ \\
\hline & Total & 493 & $100 \%$ \\
\hline \multirow{7}{*}{$\begin{array}{l}\text { Years of } \\
\text { working } \\
\text { experience }\end{array}$} & $0-5$ & 134 & $27.1 \%$ \\
\hline & $6-10$ & 141 & $28.6 \%$ \\
\hline & $11-15$ & 73 & $14.8 \%$ \\
\hline & $16-20$ & 71 & $14.4 \%$ \\
\hline & $21-25$ & 52 & $10.5 \%$ \\
\hline & 26-above & 23 & $4.6 \%$ \\
\hline & Total & 493 & $100 \%$ \\
\hline \multirow[t]{3}{*}{ Position } & Senior staff & 240 & $48.7 \%$ \\
\hline & Junior staff & 253 & $51.3 \%$ \\
\hline & Total & 493 & $100 \%$ \\
\hline
\end{tabular}

From the table above, out of all the respondents 378 representing $75.6 \%$ of them were male while 122 representing $24.4 \%$ were female. $26.6 \%$ (134) have $0-5$ years working experience $29 \%$ (145) have 6-10 years working experience $15 \%$ (75) have 11-15 years working experience $14.2 \%$ (71) have 16-20 years working experience $10.6 \%$ (53) have $21-25$ years working experience while $4.6 \%$ (23) represent 26 -above years working experience. $48.4 \%$ (242) of the respondents were senior staff, while $51.6 \%$ (258) were junior staff.

\subsection{Procedure}

The researchers employed the assistance of three research assistants; one of them is a master student and supervisee of the lead author. The other two research assistants are ex-students of the researchers. One of them is a staff of one of the oil companies used in the study, while the third one is an undergraduate, and an indigene of River state. A total of three weeks and four days were used for the administration and collection of the questionnaires. Five hundred questionnaires were administered, but only 493 were retrieved and found adequate for analysis. The response rate of the survey was 98.6. The data resulting from the scoring of the instruments and coding of the demographic items were then subjected to multiple regression and t-test statistical analyses.

\section{Results}

Two issues were investigated by the study; one of the issues was to determine the contributions of work environment and organisational culture to the prediction of employees' job performance. The second concern of the present study was to know the more potent of the two independent variables in predicting employees' job performance. The results of the data analysis are presented below: 
Table 2. Model summary of the multiple regression analysis for the combined effect of work environment and organisational culture to the prediction of job performance of employees

\begin{tabular}{llllll}
\hline & $\begin{array}{l}\text { Unstandardized } \\
\text { Coefficients B }\end{array}$ & Std. Error & $\begin{array}{l}\text { Unstandardized } \\
\text { Coefficients Beta }\end{array}$ & $\mathrm{t}$ & $\mathrm{p}$ \\
\hline (Constant) & 36.568 & .511 & & 71.612 & .000 \\
Organisational culture & .322 & .020 & .357 & 16.168 & .000 \\
Work environment & .527 & .014 & .822 & 37.262 & .000 \\
$\mathrm{R}=.873$ & & & & & \\
$\mathrm{R}^{2}=.763$ & & & & & \\
$\mathrm{R}^{2}{ }_{(\mathrm{adj})}=.762$ & & & & & \\
$\mathrm{~F}(2,490)=786.929$ & & & & & \\
$\mathrm{P}<.001$ & & & & & \\
\hline
\end{tabular}

The result above revealed that there exists positive and significant contribution of the predictor variables (work environment and Organisational culture) to the prediction of the criterion measure (job performance). The value of the coefficient of determination $\left(\mathrm{R}^{2}=0.763\right)$ implies that $76.3 \%$ of the variance in the job performance of employees in oil and gas industries in River state, Nigeria was accounted for by the combination of work environment and organisational culture. This suggests that the first hypothesis that there would be combined effect of work environment and organisational culture on job performance of employees is accepted.

To determine the contribution of each of the predictor variables to the prediction of the criterion measure, it was revealed in the above table that job performance of employees in oil and gas industries in rivers state, Nigeria could be significantly attributed to work environment and Organizational culture. These are the prominent factors that enhance job performance of employees in oil and gas industries in rivers state, Nigeria. The empirical result of the survey which depicts work environment $(\beta=.822 ; \mathrm{P}<.001)$ as the most potent predictor, followed by Organizational culture $(\beta=.357 ; \mathrm{P}<.001)$ are evidence of the positive and significant relationship existing between the predictor variables (work environment and Organisational culture) and the criterion variable (job performance). This implies that the second hypothesis that there would be significant relative contribution of work environment and organisational culture on job performance is fully supported and the hypothesis is therefore, accepted

\section{Discussion}

This study sought to investigate the contribution of work environment and organisational culture in explaining the variance in job performance of employees in oil and gas sector in River state, Nigeria. This research theme was born out of the need to provide an empirical basis for the improvement of employees' productivity; more so that the oil and gas sector remain the backbone of the nation's economy. The results revealed that the predictor variables (work environment and organisational culture) could significantly predict the criterion variable (Job performance)

The findings of this study showed a significant combine effect of work environment and organisational culture on job performance of employees in oil and gas sector in River state, Nigeria. The observed F-ratio is significant at 0.05 levels - an indication that the combine effect of the independent variables in predicting job performance could not have occurred by chance. When the independent variables were put together, they accounted for $76.3 \%$ of the variance in job performance $\left(\mathrm{R}^{2}=0.763\right)$ leaving $23.7 \%$ as unaccounted factors that could also influence job performance of employees.

In considering the relative contribution of the independent variables to the prediction of the criterion measure, it could be inferred from the result that each of the independent variables contributed significantly to the prediction of job performance of employees in oil and gas sector in River state, Nigeria with work environment being the most potent contributor.

Consequently, conclusion could be drawn that the independent variables used in the present study are good predictors of employees' job performance. However, the findings of this study is not amazing considering the fact that the various factors of work environment such as supervisor support, opportunity to get promotion, performance feedback, workplace incentives, mentoring, coaching, to mention but a few; should enhance 
employees' performance and thereby increase productivity level. Corporate culture assists the sense-making process (Mcshane \& Glinow, 2005). It helps employees understand organisational events; and when this happens, employees can communicate efficiently and effectively thereby reaching higher levels of cooperation with each other because they share common mental models of realities. The pervasive role culture plays in shaping organisational life lends plausibility to the assumptions that cultural factors may be linked with exceptional levels of organisational performance. Strong and powerful culture has been hailed as one of the major keys to improved performance (Ojo, 2010).

The findings of this study attests to the strong relationship between the predictor variables and the criterion measure; and the finding is also in agreement with the assertion of Alharbi and Alyahya (2013) that the attractions of organisation norms, values and beliefs have strong effect on employees' job performance. The results of this study also strengthen the findings of Chandrasekar (2011) who established that employees' performance level is hinged on the quality of factors of workplace environment some of which are the job aid, supervisor support and the physical workplace environment.

The finding is also consistent with the assertion of Philips, Little and Goodine (1996), and the research outcome of Ogunyemi and Awoyele (2014) that work environment that are stimulating, high in morale, caring and cooperative, with supportive co-workers and management that allow individuals to exercise responsibility and listen to ideas, are conducive to satisfy employees; and when employees are satisfied, they will give their best to the organisation.

\section{Implication of Findings}

Our study has added to the body of research in regards to the role of work environment and organisational culture on employees' job performance, particularly those in oil and gas sector in $3^{\text {rd }}$ world country like Nigeria. The findings underscore the need for employers of labour, government and policy makers to focus attention on organisational employees' friendly culture that are of some consequence to human effective functioning. Since work environment and organizational culture are significantly related to job performance, the management of oil and gas sector should ensure that Organizational culture is binding on all members and staff of the organisation as this will encourage uniformity among members of the organization and thus enhance commitment and group efficiency.

Furthermore, more attention should be given to work environment in order to make it more favourable in terms of physical facilities, information services, authority-staff relationship, and staff development so as to enhance better job performance of workers; more so that there is ample research evidences to the effect that human behaviour and effective performance are directly influenced by the factors in the work environment. The design of the work environment is the domain within which individual bahaviours are either encouraged or discouraged. Workplace is where a significant proportion of culture is formed and where teams engage in the process needed to achieve the goal of the organisation. How work environment is design affect not only how people feel, but also the work performance, their commitment to their employer, and the creation of innovative ideas (human capital) in the organisation (Vischer, 2008). The difference between a supportive work environment and an unsupportive work environment is the degree to which employees can conserve their attention and energy for their tasks, as opposed to expending it to cope with adverse environmental conditions. The observe of this argument holds that an environment conducive to the performance of work improves performance and morale (Vischer, 2008).

The limitation of our study, however, is that it represents a single industry which operates in a limited geographical area. While this factor allows for a degree of standardization, one should exercise caution in generalizing the results.

For government and employers of labour, the implications must be tempered by the nature of the company studied. Future research needs to look beyond oil and gas sector. Future research needs to look in the direction of a longitudinal as well as a more cross sectional methodology.

\section{References}

Adegbulugbe. A. O. (2002). Energy supply and demand balanced in Nigeria. Issues and options: Energy Policy Agenda for Nigeria. International Energy Services Ltd, Lagos.

Adidu, F. A., \& Ogbene, J. O. (2005). Deregulation as a tool to Economic Advancement and Social Progress: OIL. The Nigerian Experience.

Agbebaku, P. E., Edeko, S. E., \& Agbemelo, A. T. (2005). The Effect of Deregulation in the Dwonstream Sector of the oil Industry on Corruption in Nigeria. 
Ajakaiye, O. (2001). Economic Development in Nigeria: A Review of Recent Experience. Proceedings of the First Annual Monetary Policy Conference.

Alharbi, M. A., \& Alyahya, M. S. (2013). Impact of Organisational Culture on Employee Performance. International Review of Management and Business Research, 2(1), 168-175.

Anya, A. O. (2002). Science, Oil and the future of Nigeria Economy. The Guardian (Lagos), 16.

Argyle, M. (1989). The Social Psychology of Work (2nd ed.). Harmonds worth: Penguin.

Assael, H. (2000). Overview of petroleum industry, Nigeria oil and gas (1). Global Journal of Management and Business Research, 10(6), 11-13.

Boles, M., Pelletier, B., \& Lynch, W. (2004). The relationship between health risks and work productivity. $\begin{array}{llll}\text { Journal of Occupational and Environment Medicine, 46(7), } & \text { 737-745. }\end{array}$ http://dx.doi.org/10.1097/01.jom.0000131830.45744.97

Brooks, I. (2006). Organizational Behaviour: Individuals, Groups and Organisation. Essex: Pearson Education Limited.

Burmer, R., \& Evans, A. J. (2008). Target Zero: A culture of Safety. Deference Aviation Safety Central Journal, 5, 22-27.

Burnstein, C., \& Fisk, D. (2003). The Federal government productivity improvement program: Status and Agenda. Public Budgeting Finance, 7, 36-48. http://dx.doi.org/10.1111/1540-5850.00762

Cecunc, E. (2004). Improving Employee productivity in Regulating Industries. New York: Academic Press.

Central Bank of Nigeria. (2002). The changing Structure of the Nigeria economy and implications for Development. Abuja: CBN.

Chandrasekar, K. (2011).Workplace environment and its impact on organisational performance in public sector organizations. International Journal of Enterprise Computing and Business System, 1(1), 1-20.

Chukwu, I (2002). Crude oil development. The Post Express, pp. A24, A25.

Clements-Croome, D. (Ed.). (2000). Creating the productive workplace. London: E \& FN Spoon.

Clements-Croome, D. (2006). Creating the productive workplace. (2nd ed.). Oxford, England: Taylor and Francis.

Dasanyake, S. W. S. B., \& Mahakalanda, I. (2008). A literature survey on organizational culture and innovation, In I. M. Nejati, A. Shefaei, \& M. Nejatin (Eds.), Issues in Global Business and Management Research: Proceedings of the 2008 International Online Conference on Business and Management (IOCBM 2008) (pp. 539-550). Florida: Boca Raton.

Ekpu, R. (2004). Associated gas utilization. Nigeria's Oil and Gas, 3(8), 17-18.

Guion, R. M. (1997). Assessment measurement and prediction for personnel decisions Mahwah. NJ: Lawrence Erlbaum Associates.

Kerr, J., \& Slocum, J. W. (2005). Managing corporate culture through reward systems. Academy of Management Executive, 19, 130-138. http://dx.doi.org/10.5465/AME.2005.19417915

Kohun, S. (1992). Business Environment. Ibadan: University Press

Litwin, G. H., \& Stinger, R. A. J. (1998). Motivation organisational Climate. Boston, MA: Harvard University Press.

McShane, S. L., \& Glinow, M. A. (2005). Organizational Behaviour: Emerging Realities for Workplace Revolution. New York: McGraw-Hill, International Edition.

Newsham, G. R., Veitch, J., Charles, K. E., Clinton, J. G., Marquardt, J. G., Bradley, J. S., Shaw, C. Y., \& Readon, J. (2004). Environmental satisfaction in open plan environments: Relationships between physical variables. Technical Report, 153.

NNPC. (1981). Necector (House Journal), 2(2), 18.

NNPC. (2004). Necector (House Journal), 25(3), 7.

Ogunyemi, A. O., \& Awoyele, O. T. (2014). The Buffering effect of critical life event, organisational climate and social support on subjective well-being of bank workers in southwest Nigeria. Journal of Education and Practice, 5(8), 159-168. 
Ojo, O. (2010). Organisational Culture and Cooperate Performance: Empirical Evidence from Nigeria. Journal Business Systems, Governance and Ethics, 5(2).

Philips, S. D., Little, B. R., \& Goodine, L. A. (1996). Organizational Climate and personal project: Gender differences in the public services. Retrieved from http://www.csps-efpc.gc.ca/research/publications/pdfs/respr20epdf+organization

Schein, E. H. (1992). Organizational Culture and Leadership (2nd ed.). San Francisco: Jossey-Bass.

Shani, A. B., \& Lau, J. B. (2005). Behaviour in Organizations: An Experimental Approach (8th ed.). New York: Mc Gram-Hill Irwin.

Shikdar, A. A., \& Sawaqed, N. M. (2013). Worker productivity, and occupational health and safety issues in selected industries. Computers and Industrial Engineering, 45(4), 563-572. http://dx.doi.org/10.1016/S0360-8352(03)00074-3

Stewart. D. (2010). Growing the Corporate Culture. Retrieved from https//www.wachovia.com/foundation/v/index.jsp?vgnextoid=ab411f07760aa110VgnVCM1000004b0d187 2RCRD\&vgnextfmt $=$

Stringer, R. (1998). Leadership and organisational climate. In Upper Saddle River. NJ: Prentice Hall.

Varelas, E. (2009). Sizing Up Cultural Fit. T+ D Magazine, 1(1), 76-77.

Viasher, J. C. (2007). The effect of the physical environment on job performance: Towards a therapeutical model of workspace stress. Journal of Stress and Health, 23, 175-184. http://dx.doi.org/10.1002/smi.1134

Vischer, J. C. (2008). Towards a user-centred theory of the built environment. Building research and information, 36(3), 231-240. http://dx.doi.org/10.1080/09613210801936472

Wiegmann, D., Zhang, H., von Thaden, T., Sharma, G., \& Mitchell, A. (2003). A synthesis of safety culture and safety climate research. Technical report prepared for FAA. (Technical Report No. ARL-02-3/FAA-02-2). Savoy, IL: Aviation Research Lab Institute of Aviation, University of Illinois at Urbana-Champaign.

Yusuf, N., \& Metiboba, S. (2012). Work Environment and Job Attitude among Employees in Nigerian. Journal of Sustainable Society, 1(2), 36-43.

\section{Copyrights}

Copyright for this article is retained by the author(s), with first publication rights granted to the journal.

This is an open-access article distributed under the terms and conditions of the Creative Commons Attribution license (http://creativecommons.org/licenses/by/3.0/). 